\title{
Working Fluid Candidates Selection for 100kW Ocean Thermal Power Generation Based on Environmental, Safety, and Thermodynamic Constrains
}

\author{
B. Halimi ${ }^{1 *}$, R. Y. Atolah ${ }^{1}$, E. Julianti ${ }^{2}$, I. M.W. Kastawan ${ }^{3}$ \\ ${ }^{1}$ School of Electrical Engineering and Informatics, Institut Teknologi Bandung \\ Jl. Ganesha 10 Bandung 40132 \\ ${ }^{2}$ School of Pharmacy, Institut Teknologi Bandung \\ Jl. Ganesha 10 Bandung 40132 \\ ${ }^{3}$ Department of Energy Conversion Engineering, Politeknik Negeri Bandung \\ Jl. Gegerkalong Hilir, Bandung \\ burhan@konversi.ee.itb.ac.id ${ }^{1 *}$, elin_julianti@fa.itb.ac.id ${ }^{2}$,wiwit.kastawan@ polban.ac.id ${ }^{3}$
}

\begin{abstract}
Due to its equatorial location, Indonesia has a huge amount of ocean thermal energy resource. However, this alternative renewable energy resource is still not well developed yet. In this paper, a selection procedure of working fluid for a $100 \mathrm{~kW}$ ocean thermal power generation is presented. The screening process was based on environmental, safety and thermodynamic constrains to obtain the best working fluid for this application. Five working fluid candidates are analyzed i.e. ammonia, butane, butene, isobutane, and isobutene. In term of environmental and safety aspects, ammonia is the best solution. But in thermodynamic point of view, isobutane shows the highest power conversion efficiency of $6.13 \%$, whereas ammonia's efficiency is only $1.87 \%$ for the same power output.
\end{abstract}

Keywords: OTEC, working fluid, ODP, GWP, GSF, efficiency.

\section{Introduction}

As one of archipelago countries, Indonesia has 17,504 islands; around 10,000 of them can be categorized as small islands; which made it as the second longest coastline in the world [1]. The existence of these small islands, some of them are unfortunately isolated, is a challenging issue to deal with in term of how to provide the electricity power supply for them. Although the current national electricity ratio is $98 \%$, there are some areas with less $90 \%$ or even less than $70 \%$ [2].

\subsection{Power Generations in Indonesia}

Nowadays, the majority of Indonesia's power generations are dominated by fossil-fueled power plants [2]. In the fact, Indonesia has large and very diverse renewable energy resources which are still not optimally developed as tabulated in Table 1 [3]. The renewable energy utilizations are currently focused on geothermal, hydro, biomass, solar and wind energy. But, their utilizations are relatively smaller than their existed potentials. Moreover, Table 1 also shows the other renewable energy alternatives which are not explored yet "the blue ocean energy" such as wave energy, tide and tidal energy, and ocean thermal energy. Total ocean renewable energy resources are $63,801 \mathrm{MW}$ which $7.52 \%$ of them are contributed by the tide and tidal energy ones. The previous research reported that the tidal energy, especially the current one, in the narrow straits is considerably much higher in archipelagos, such as in the Nusa Tenggara and Maluku Islands including Bali Strait [4]. Another prospective renewable ocean energy is the ocean

TELKA, Vol.6, No.1, Mei 2020, pp. 20 28

ISSN (e): 2540-9123

ISSN (p): 2502-1982 
thermal energy which has resources of 41,012 MW. This valuable energy is much higher than biomass resources and almost half of hydro resources in Indonesia. Based on this fact, this energy should be considered as one of alternative candidates for providing electrical power supply in Indonesia.

Figure 1 illustrates potential locations for ocean thermal power plant or ocean thermal energy conversion (OTEC) in Indonesia [5]. Moreover, Mentawai Islands Regency with its chain of around seventy islands in West Sumatera Province is another prospective site for OTEC $[6,7]$.

In this paper, an investigation of prospective working fluid candidates for OTEC is presented. The working fluid selection is one of important steps to obtain the most appropriate working fluid for gaining the best OTEC system in term of technical and nontechnical aspects. The determination of the best potential working fluid is not only based on the environmental and safety consideration. Considering the inherent low efficiency issue of OTEC-based power generation, an analytic thermodynamics-based analysis is also performed to obtain the best system efficiency.

Table 1. Renewable energy resources in Indonesia [3].

\begin{tabular}{cccc}
\hline Energy Type & Resources & Potential & Installed Capacity \\
\hline Geothermal & & $29,544 \mathrm{MW}$ & $1,948.3 \mathrm{MW}$ \\
Hydro & $75,091 \mathrm{MW}$ & $45,379 \mathrm{MW}$ & $4,431.59 \mathrm{MW}$ \\
Mini-micro hydro & & $19,385 \mathrm{MW}$ & $267.79 \mathrm{MW}$ \\
Biomass & $35,654 \mathrm{MWe}$ & & $142.02 \mathrm{MW}$ ( off grid ) \\
Solar energy & $4.80 \mathrm{kWh} / \mathrm{m}^{2} / \mathrm{hari}$ & & $24.42 \mathrm{MW}$ \\
Wind energy & & $970 \mathrm{MW}$ & $143.03 \mathrm{MW}$ \\
Wave energy & $17,989 \mathrm{MW}$ & & \\
OTEC (Ocean Thermal & $41,012 \mathrm{MW}$ & & \\
Energy Conversion) & & & \\
Tide and tidal power & $4,800 \mathrm{MW}$ & & \\
& &
\end{tabular}

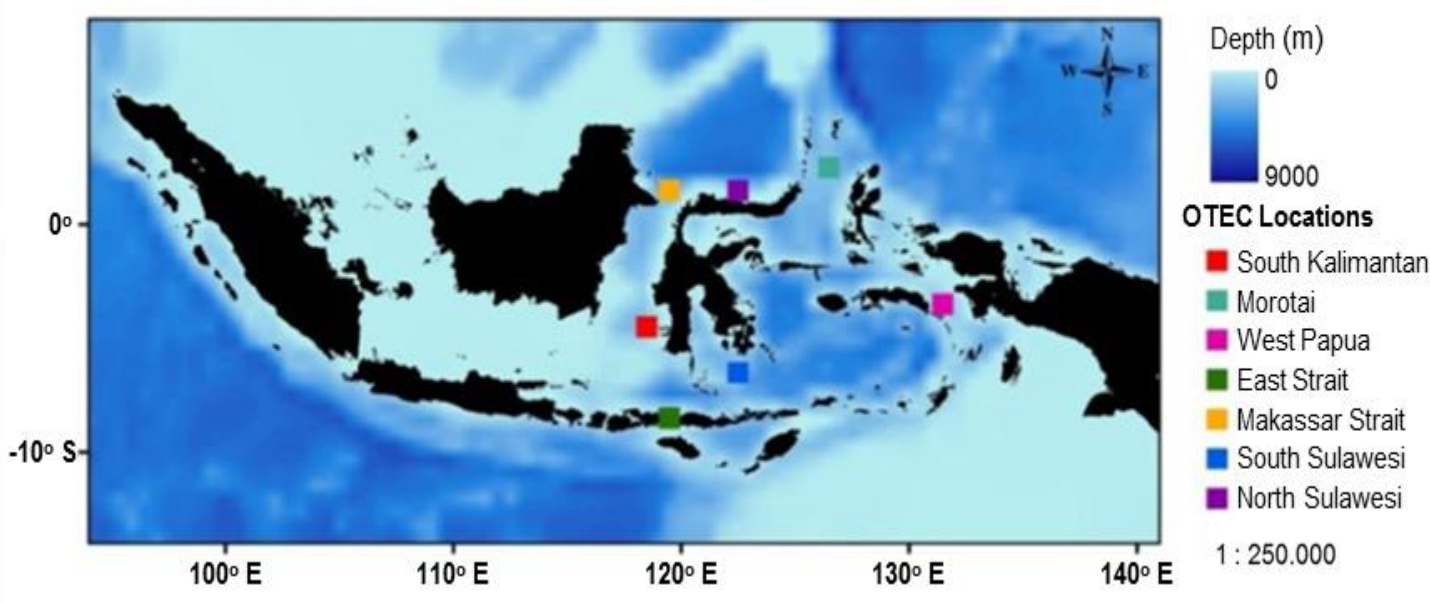

Figure 1. Map of bathymetry Indonesian seas for OTEC sites [5].

\subsection{Principle of Ocean Thermal Power Generation}

The basic principle of an ocean thermal power generation or OTEC is based on the natural characteristic of seawater which has a thermal difference between seabed and surface one. The surface seawater's temperature is quite warmer than the seabed's one as illustrated in Figure 2 [8], [9]. This phenomenon is dominantly influenced by the solar radiation. In this paper, the area of Indonesia territorial waters in $125^{\circ} \mathrm{E} 30^{\circ} \mathrm{N}-127.5^{\circ} \mathrm{E} 5^{\circ} \mathrm{N}$ are selected as the location candidate for OTEC. In this region, the surface and deep layer $(1,000 \mathrm{~m})$ seawater temperatures are in the range of $28.44-31.23^{\circ} \mathrm{C}$ and $4-5^{\circ} \mathrm{C}$, respectively [10]. 
By adopting the natural characteristic of ocean water, a basic scheme of OTEC is described in Figure 3. The surface water which has warmer temperature is used to evaporate a low boiling temperature working fluid for generating steam. Then, the steam is guided to rotate a steam turbine which direct coupled with a generator. From the steam turbine, the working fluid is reconverted to the fluid form. This conversion is performed in a condenser which uses the colder temperature seawater as a heat extraction media from the working fluid. In this liquid form, the working fluid is easily back pumped to the evaporator for making a complete Rankine power cycle.

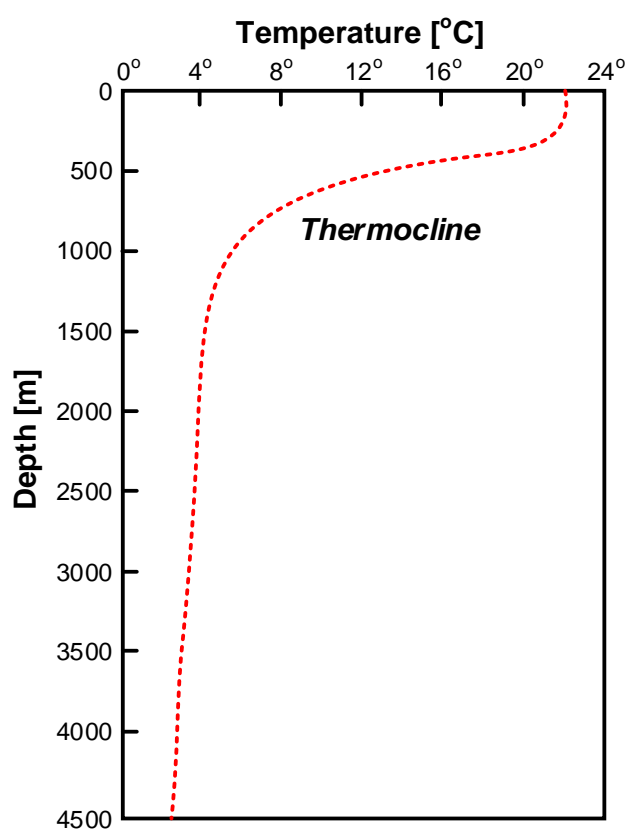

Figure 2. Typical thermocline ocean water characteristic [8], [9].

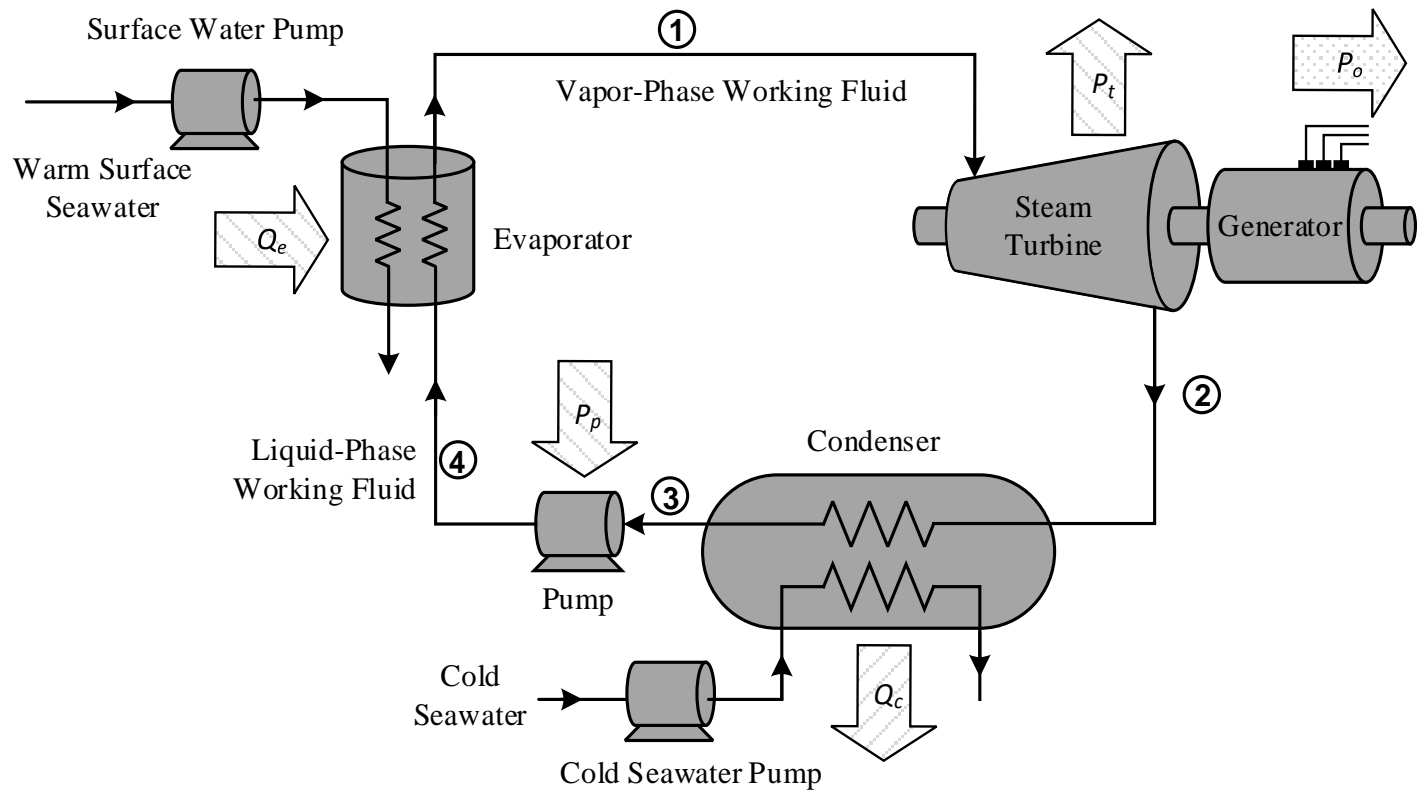

Figure 3. Basic principle of Ocean Thermal Power Generation or OTEC 


\section{Research Method}

There are several criteria have to be considered for working fluid candidates selection. They must cover some important aspects such as environmental sustainability, ozone depletion potential (ODP), global warning potential (GWP), safety (non-flammable, non-toxic and noncorrosive) as well as some critical thermodynamic constrains [11].

Due to the quite narrow temperature difference range in OTEC power cycle, the first requirement is that the working fluid should have a low boiling temperature. Considering this factor, water is quite not applicable for OTEC power cycle. As tabulated in Table 2, the normal boiling temperature of water is $99.97^{\circ} \mathrm{C}$. This temperature is much higher than the annual average temperature of surface seawater. Table 2 also shows other working fluids which more suitable for OTEC application i.e. ammonia, butane, butene, isobutane, and isobutene. The temperature and pressure of these working fluids' critical point are much lower than water as well as their normal boiling temperature. Thus, these five working fluids will be more detail analyzed in term of power cycle thermal efficiency.

Table 2. Thermodynamic properties of working fluid candidates [12]

\begin{tabular}{lcccc}
\hline \multirow{2}{*}{ Working Fluid } & \multicolumn{3}{c}{ Critical Point } & \multirow{2}{*}{$\begin{array}{c}\text { Normal Boiling } \\
\left({ }^{\circ} \mathrm{C}\right)\end{array}$} \\
\cline { 2 - 4 } & $\begin{array}{c}\text { Temperature } \\
\left({ }^{\circ} \mathrm{C}\right)\end{array}$ & $\begin{array}{c}\text { Pressure } \\
\text { MPa })\end{array}$ & $\begin{array}{c}\text { Density } \\
\left(\mathrm{kg} / \mathrm{m}^{3}\right)\end{array}$ & $\begin{array}{c}\left.{ }^{3}\right) \\
\text { Water }\left(\mathrm{H}_{2} \mathrm{O}\right)\end{array}$ \\
\hline Ammonia $\left(\mathrm{NH}_{3}\right)$ & 1373.95 & 22.064 & 322.0 & 99.97 \\
Butane $\left(\mathrm{CH}_{3}-2\left(\mathrm{CH}_{2}\right)-\mathrm{CH}_{3}\right)$ & 151.98 & 11.333 & 225 & -33.33 \\
Butene $\left(\mathrm{CH}_{3}-\mathrm{CH}_{2}-\mathrm{CH}=\mathrm{CH}_{2}\right)$ & 146.14 & 4.796 & 228 & -0.49 \\
Isobutane $\left(\mathrm{CH}_{2}\left(\mathrm{CH}_{3}\right)_{3}\right)$ & 134.66 & 3.629 & 237.89 & -6.31 \\
Isobutene $\left(\mathrm{CH}_{2}=\mathrm{C}\left(\mathrm{CH}_{3}\right)_{2}\right)$ & 144.94 & 4.010 & 225.5 & -11.75 \\
\hline
\end{tabular}

Moreover, the ODP and GWP values of the working fluid candidates must be low and less 150, respectively [13]. Based on NFPA 704 standard, the global safety factor (GSF) can be easily determined by using a set of criteria i.e. health $(H)$, instability $(I)$ and flammability $(F)$ activities of the working fluid as formulated in Eq. (1) as follows [11]

$$
G S F=(\alpha \times H)+(\beta \times I)+(\gamma \times F),
$$

where $\alpha, \beta$, and $\gamma$ are weightage factor for each safety criterion. These weightage factors are adopted to give different weight for the working fluid hazard. The most concern is given to the flammability aspect $(\gamma=45 \%)$ due to its possible risk of auto-ignition hazard in the case of leakage. For the similar reason, the instability factor should be given more attention by adopting $\beta=35 \%$. Lastly, the health hazard's weightage factor is $\alpha=20 \%$. NFPA 704 stated each safety's value in the range between 0 and 4 [15]. The GSF should be less than 2.5. Table 3 shows safety factors of the selected working fluid candidates. Except isobutene which normally stable but can become unstable at elevated temperatures and pressure, all working fluid candidates is quite safe and may be adopted for OTEC. However, the isobutane will be covered in the computational analysis to investigate in term of thermodynamic point of view.

Table 3. Safety factor of working fluid candidates

\begin{tabular}{lcccccc}
\hline Working Fluid & ODP & GWP & H & F & I & GSF \\
\hline Ammonia & 0 & 0 & 3 & 1 & 0 & 1.05 \\
Butane & 0 & $7[16]$ & 1 & 4 & 0 & 2.00 \\
Butene & 0 & $3[17]$ & 1 & 4 & 0 & 2.00 \\
Isobutane & 0 & $5[18]$ & 0 & 4 & 0 & 1.80 \\
Isobutene & 0 & - & 2 & 4 & 1 & $\mathbf{2 . 5 5}$ \\
\hline
\end{tabular}

ISSN (e): 2540-9123

ISSN (p): 2502-1982 


\section{Results and Discussion}

As illustrated in Figure 3, an OTEC power cycle is basically a Rankine power cycle. The input thermal power can be calculated as follows [8], [9]

$$
Q_{e}=\dot{m}_{s w} c_{p e}\left(T_{s w-i}-T_{s w-o}\right),
$$

where $Q_{e}$ is the evaporator thermal power, $\dot{m}_{s w}$ is the mass flow rate of surface seawater, $c_{p e}$ is the heat transfer constant between surface seawater and working fluid, $T_{s w-i}$ and $T_{s w-o}$ are the surface seawater temperature on the inlet and outlet sides, respectively. By using the similar calculation, the condenser can be formulated as follows

$$
Q_{c}=\dot{m}_{c w} c_{p c}\left(T_{c w-o}-T_{c w-i}\right),
$$

where $Q_{c}$ is the condenser thermal dissipation, $\dot{m}_{c w}$ is the mass flow rate of cold seawater, $c_{p c}$ is the heat transfer constant between cold seawater and working fluid, $T_{c w-i}$ and $T_{c w-o}$ are the cold seawater temperature on the inlet and outlet sides, respectively.

To check the performance of all working fluid candidates, the EBSILON®Profesional software is adopted to perform various computation analyses. The scheme of power generation system is illustrated in Figure 3. For the analysis, the output power is kept constant at $100 \mathrm{~kW}$. For providing a more reasonable comparison, the mass flow rate of working fluid is also maintained at around $4 \mathrm{~kg} / \mathrm{s}$ for all working fluid. The temperatures of surface and cold water are set to be $29^{\circ} \mathrm{C}$ and $4^{\circ} \mathrm{C}$, respectively. The generator efficiency is assumed as $96 \%$ with the isentropic efficiency of turbine and pump of $88 \%$ and $80 \%$, respectively. Then, the calculated variables are the injected heat from surface seawater, absorbed heat by cold seawater, and also working fluid thermodynamic properties at each state. Then, the system efficiency can be easily calculated by using following formula

$$
\eta=\frac{P_{\text {output }}}{P_{\text {input }}} \times 100 \%
$$

Table 4 summarizes the computational analysis results. As shown in Table 4, except ammonia, the transferred heat in the evaporator and the condenser are quite similar among the working fluid candidates. For the same power output, ammonia requires the highest amount of heat to convert it from liquid phase to vapor one. Even though the pump's power $(1.058 \mathrm{~kW})$ is the smallest one, this requirement makes its efficiency much smaller than the other working fluid candidates. The contrasted result is shown for isobutane working fluid. The isobutane's efficiency $(6.13 \%)$ is the highest one among the others by drawing the highest pumping power of $1.892 \mathrm{~kW}$. Thus, considering the efficiency constrain, isobutane can be considered as the most appropriate working fluid for OTEC application. For isobutene, although it was quite out of the safety criteria range, this working fluid shows a good performance in term of the power conversion efficiency. This working fluid selection mechanism might be applied to any other power generations with different power capacities.

Moreover, for providing more complete cycle process illustration, the $T-s$ diagrams of all working fluid are figured in Figure 4-8. The important thermodynamic properties of each state are tabulated in Table 4. Except ammonia, all working fluid candidates are categorized as dry fluid type as illustrated in Figure 5-8. A dry fluid type has a $T$-s diagram with $d s / T>0$ as depicted in the shape of $T$-s diagram. The different $T$-s diagram is shown in ammonia's one. Ammonia is classified as wet fluid which has $d s / T<0$ characteristic as presented in Figure 4. Also, as shown in Figure 4-8, due to the tight narrow temperature difference margin in OTEC, the loci of state 3 and 4 are looked in the same spot. Even thought, they are actually in the different position as zoomed in in the inserted view. 
Table 4. Computational analysis results

\begin{tabular}{|c|c|c|c|c|c|c|}
\hline & Parameter & Ammonia & Butane & Butene & Isobutane & Isobutene \\
\hline \multirow{4}{*}{ State 1} & $T_{I}\left({ }^{\circ} \mathrm{C}\right)$ & 28 & 28 & 28 & 28 & 28 \\
\hline & $P_{I}($ bar $)$ & 6.40 & 2.66 & 3.25 & 3.80 & 3.3 \\
\hline & $h_{l}(\mathrm{~kJ} / \mathrm{kg})$ & 1662.233 & 625.254 & 434.132 & 592.013 & 436.560 \\
\hline & $s_{1}(\mathrm{~kJ} / \mathrm{kgK})$ & 6.109 & 2.422 & 1.456 & 2.312 & 1.466 \\
\hline \multirow{4}{*}{ State 2} & $T_{2}\left({ }^{\circ} \mathrm{C}\right)$ & 16.281 & 9.164 & 7.333 & 9.370 & 7.674 \\
\hline & $P_{2}$ (bar) & 5.200 & 1.250 & 1.600 & 1.875 & 1.600 \\
\hline & $h_{2}(\mathrm{~kJ} / \mathrm{kg})$ & 1637.766 & 599.348 & 409.345 & 568.269 & 411.238 \\
\hline & $s_{2}(\mathrm{~kJ} / \mathrm{kgK})$ & 6.121 & 2.435 & 1.468 & 2.323 & 1.479 \\
\hline \multirow{4}{*}{ State 3} & $T_{3}\left({ }^{\circ} \mathrm{C}\right)$ & 5.229 & 5.166 & 6.036 & 5.123 & 5.282 \\
\hline & $P_{3}$ (bar) & 5.200 & 1.250 & 1.600 & 1.875 & 1.600 \\
\hline & $h_{3}(\mathrm{~kJ} / \mathrm{kg})$ & 367.427 & 212.025 & 27.099 & 211.788 & 27.698 \\
\hline & $s_{3}(\mathrm{~kJ} / \mathrm{kgK})$ & 1.559 & 1.043 & 0.099 & 1.043 & 0.101 \\
\hline \multirow{4}{*}{ State 4} & $T_{4}\left({ }^{\circ} \mathrm{C}\right)$ & 5.266 & 5.246 & 6.136 & 5.244 & 5.381 \\
\hline & $P_{4}$ (bar) & 6.450 & 2.710 & 3.300 & 3.850 & 3.350 \\
\hline & $h_{4}(\mathrm{~kJ} / \mathrm{kg})$ & 367.674 & 212.332 & 27.447 & 212.217 & 28.055 \\
\hline & $s_{4}(\mathrm{~kJ} / \mathrm{kgK})$ & 1.559 & 1.044 & 0.099 & 1.043 & 0.102 \\
\hline \multicolumn{2}{|l|}{$m(\mathrm{~kg} / \mathrm{s})$} & 4.266 & 4.233 & 4.211 & 4.396 & 4.122 \\
\hline \multicolumn{2}{|l|}{$P_{t}(\mathrm{~kW})$} & 104.167 & 104.167 & 104.167 & 104.167 & 104.167 \\
\hline \multicolumn{2}{|l|}{$Q_{e}(\mathrm{~kW})$} & 5522.677 & 1747.713 & 1712.538 & 1669.569 & 1683.870 \\
\hline \multicolumn{2}{|l|}{$Q_{c}(\mathrm{~kW})$} & 5419.357 & 1639.362 & 1609.626 & 1567.081 & 1580.967 \\
\hline \multicolumn{2}{|l|}{$P_{p \text {-shaft }}(\mathrm{kW})$} & 1.058 & 1.366 & 1.467 & 1.892 & 1.475 \\
\hline \multicolumn{2}{|l|}{$P_{o}(\mathrm{~kW})$} & 100 & 100 & 100 & 100 & 100 \\
\hline \multicolumn{2}{|c|}{ Efficiency $(\%)$} & 1.87 & 5.88 & 6.00 & 6.13 & 6.10 \\
\hline
\end{tabular}

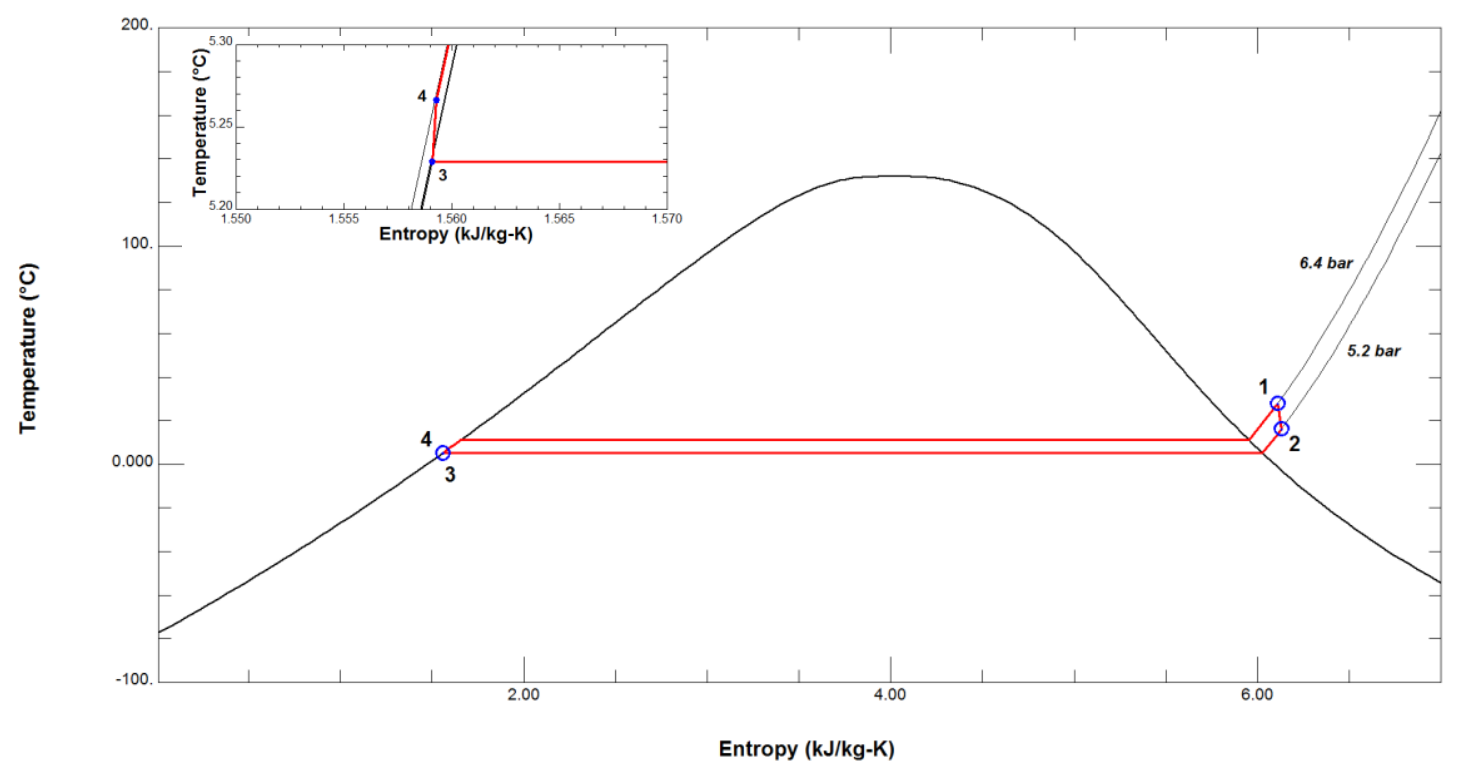

Figure 4. T-s diagram of ammonia working fluid 


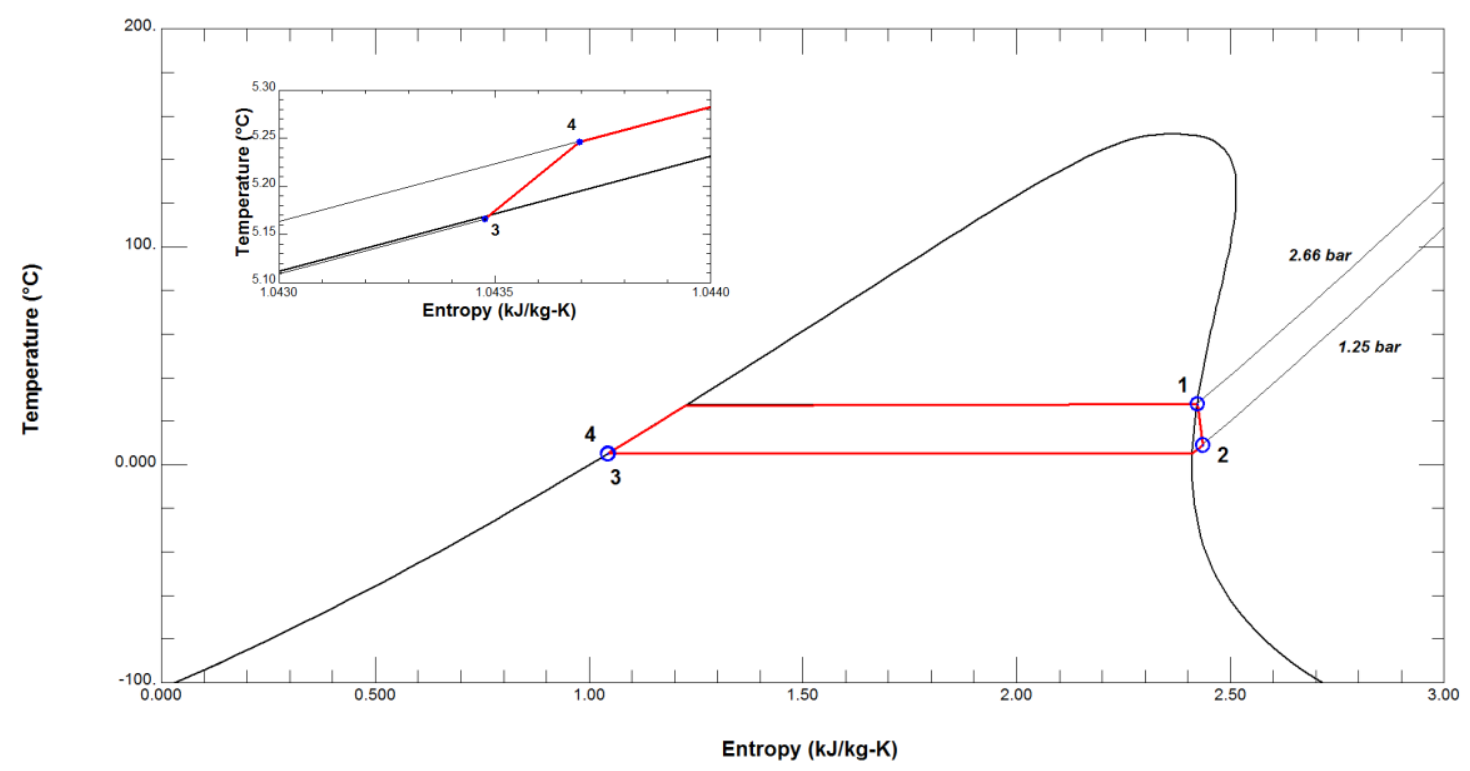

Figure 5. $T$-s diagram of butane working fluid

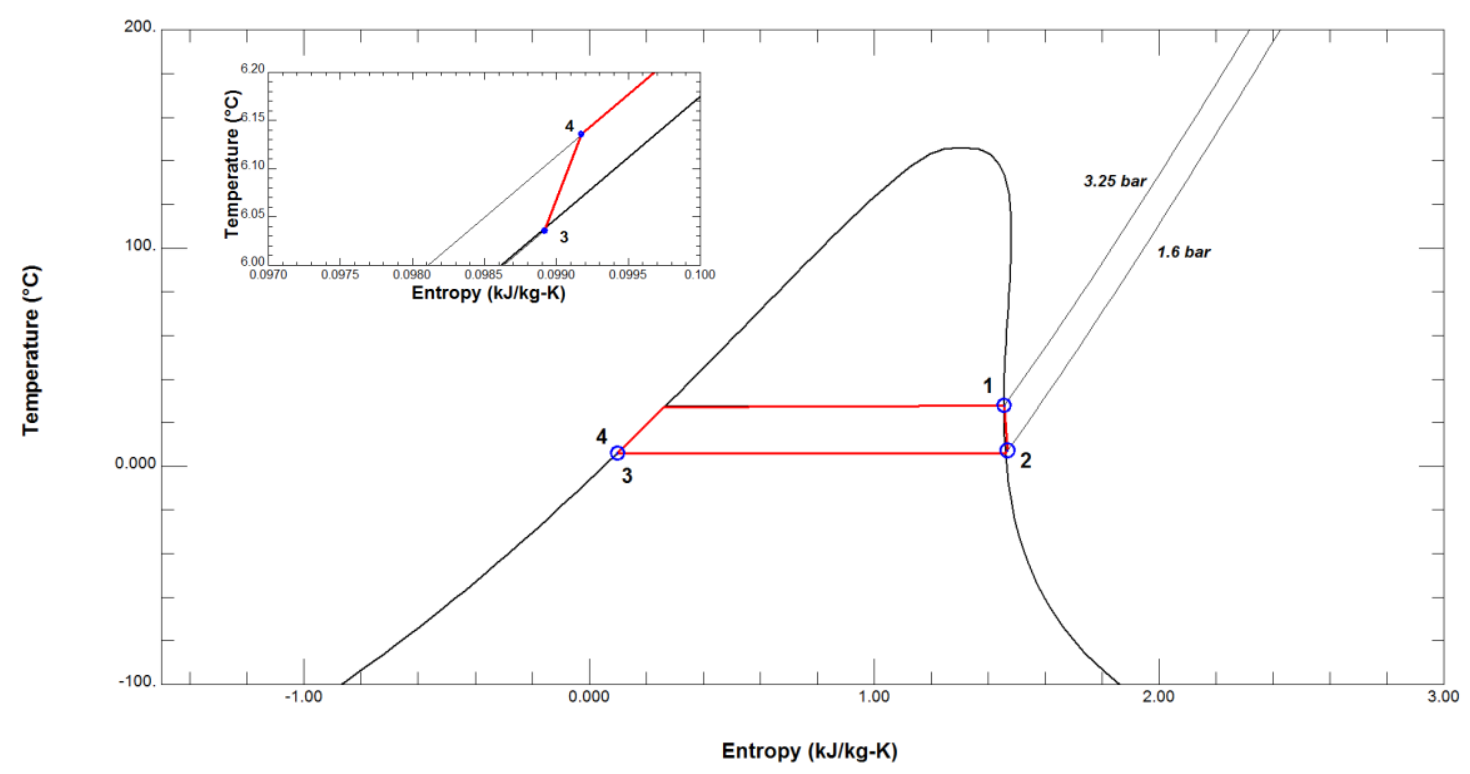

Figure 6. T-s diagram of butene working fluid 


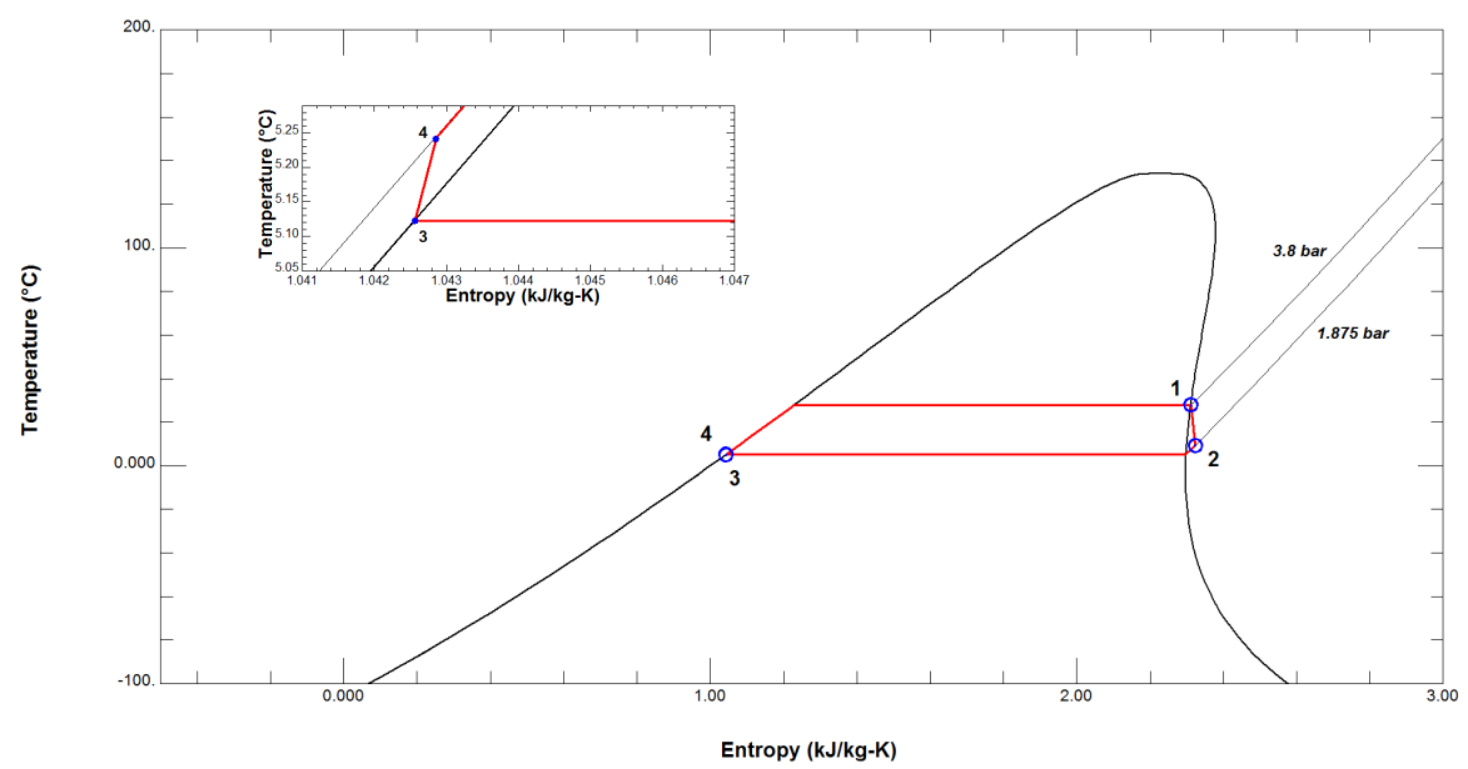

Figure 7. $T$-s diagram of isobutane working fluid

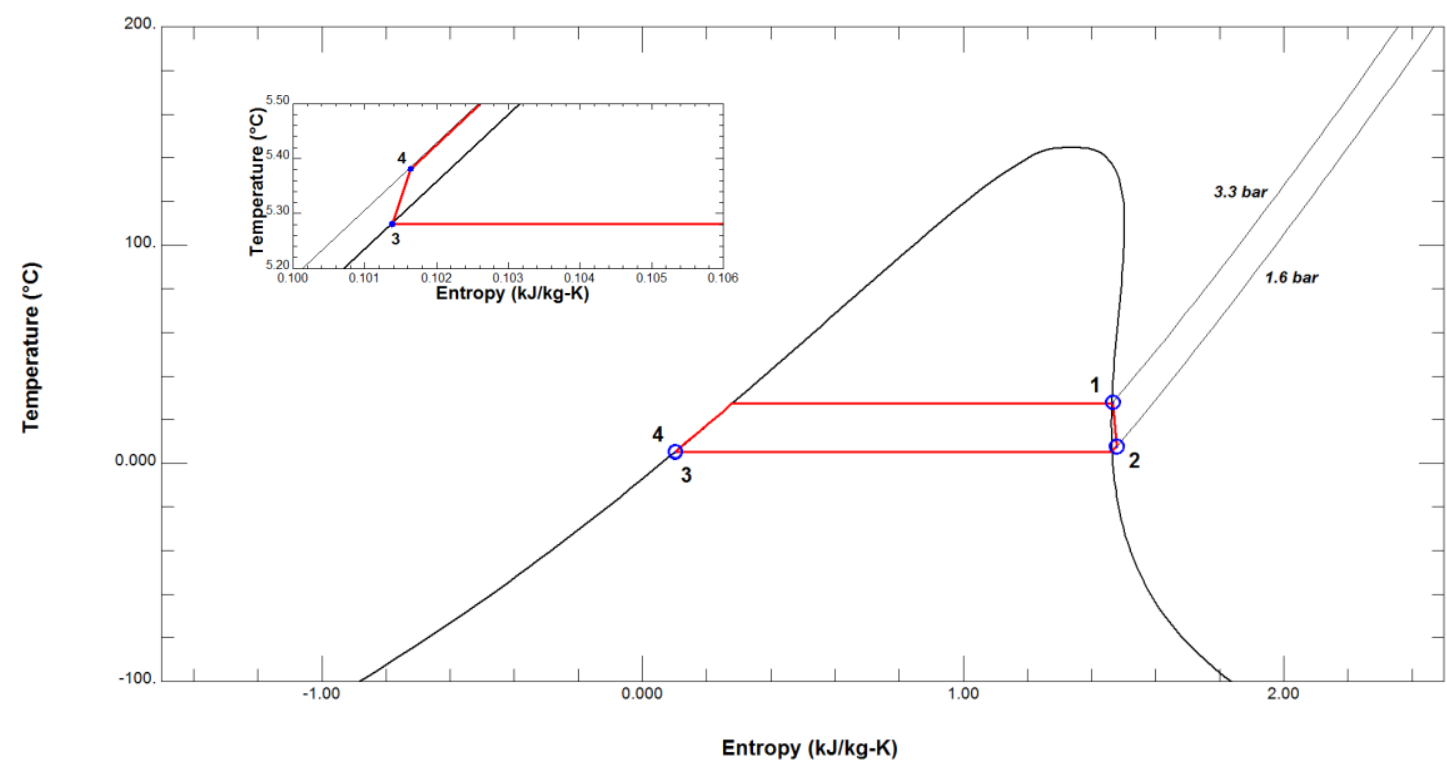

Figure 8. $T$-s diagram of isobutene working fluid

\section{Conclusions}

In this paper, a selection procedure of working fluid for a $100 \mathrm{~kW}$ ocean thermal power generation was presented. The screening process was based on environmental, safety and thermodynamic constrains to obtain the best working fluid for this application. Five working fluid candidates were analyzed i.e. ammonia, butane, butene, isobutane, and isobutene. In term of environmental and safety aspects, ammonia is the best solution. But in thermodynamic point of view, isobutane demonstrated the highest power conversion efficiency of $6.13 \%$, whereas ammonia's efficiency is only $1.87 \%$ for the same power output. 


\section{Acknowledgements}

This work was supported by the Ministry of Research and Technology/National Agency for Research and Innovation, Indonesia.

\section{References}

[1] Poernomo, Achmad \& Kuswardani, Anastasia. (2019). Ocean Policy Perspectives: The Case of Indonesia: Politics and Policy for Threatened Seas. DOI:10.1017/9781108502238.007.

[2] PT PLN (Persero), Rencana Usaha Penyediaan Tenaga Listrik PT PLN (Persero) 20192028, 2019

[3] Pusat Pengkajian Industri Proses dan Energi BPPT, Outlook Energi Indonesia 2019, 2019

[4] H. Matsuda, et. al.," Harvesting ocean energy with a small-scale tidal-current turbine and fish aggregating device in the Indonesian Archipelagos," Sustainable Energy Technologies and Assessments, Vol. 35, pp. 160-171, 2019

[5] M. L. Syamsiddin, et. al, "OTEC Potential in the Indonesian Seas," Energy Procedia, Vol 65, pp. 215-222, 2015

[6] R. Adiputra dan T.Utsunomiya, "Stability based approach to design cold-water pipe (CWP) for ocean thermal energy conversion (OTEC)," Applied Ocean Research, Vol. 92, 101921, Nov. 2019

[7] R. Adiputra, et.al., "Preliminary design of a $100 \mathrm{MW}$-net ocean thermal energy conversion (OTEC) power plant study case: Mentawai island, Indonesia," Journal of Marine Science and Technology, Vol. 25, pp. 48-68, 2020

[8] B. Halimi, "Amonia sebagai Fluida Kerja Pembangkit Listrik Tenaga Panas Laut Alternatif Solusi Kelistrikan di Indonesia," Seminar Nasional Sains dan Teknologi, Jakarta, 1-2 November 2017

[9] B. Halimi, R. Y. Atolah, "Analysis of $100 \mathrm{~kW}$ Ocean Thermal Power Plant with Butene as Working Fluid," The First Maluku International Conference on Marine Science and Technology, 24-26 October 2018, Ambon, Indonesia

[10] D. A. Gammaranti, "Pemetaan Potensi Energi Panas Laut di Kepulauan Sangihe-Talaud," in Institut Teknologi Bandung, Bandung, 2016.

[11] K. Darvish, et. al., "Selection of Optimum Working Fluid for Organic Rankine Cycles by Exergy and Exergy-Economic Analyses," Sustainability, 7, pp. 15362-15383, 2015

[12] NIST. 2013, NIST Reference Fluid Thermodynamic and Transport PropertiesREFPROP, User's Guide

[13] R. Minjares," Refrigerants for light-duty passenger vehicle air conditioning systems," In. Proc. ICCT, 2011

[14] M. Imran, et. al., "Multi-objective optimization of organic Rankine cycle power systems for waste heat recovery on heavy-duty vehicles," in Proc. The $31^{\text {st }}$ International Conference on Efficiency, Cost, Optimization, Simulation, and Environmental Impact of Energy Systems, Gumaraes, Portugal, June, 2018

[15] Cameo Chemicals, "Chemical Datasheet," https://cameochemicals.noaa.gov/chemical/

[16] O. Hodnebrog et,al. ," Lifetimes, direct and indirect radiative forcing, and globalwarming potentials of ethane (C2H6), propane (C3H8), and butane (C4H10)," Atmos. Sci. Lett.2018;19:e804,

[17] M. Hauschild and H. Wenzel, " Environmental of Assessment of Products, Volume 2: Scientific background," Chapman \& Hall, 1998

[18] California Air Resources Board, High-GWP Refrigerants, https://ww2.arb.ca.gov/resources/documents/high-gwp-refrigerants 